\title{
UBQLN4 Gene
}

National Cancer Institute

\section{Source}

National Cancer Institute. UBQLN4 Gene. NCI Thesaurus. Code C118579.

This gene may be involved in the regulation of protein degradation. 